\title{
Substance P Injected into the Hypothalamic Supraoptic Nucleus Causes Antidiuresis through the Release of Arginine-Vasopressin in Water-Loaded and Ethanol-Anesthetized Rats
}

\author{
Mayumi Mori, Hiromi Tsushima and Tomohiro Matsuda ${ }^{\#}$ \\ Department of Pharmacology, Nagoya City University Medical School, Kawasumi, Mizuho-ku, Nagoya 467, Japan
}

Received November 26, 1992 Accepted February 3, 1993

\begin{abstract}
The effects of injection of substance P (SP) into the hypothalamic supraoptic vasopressinergic nucleus (SON) in water-loaded and ethanol-anesthetized rats were examined. Substance $P$ and its analog [D-Pro $\left.{ }^{2}, \mathrm{D}-\mathrm{Trp}^{7,9}\right] \mathrm{SP}$ induced marked decreases in urine outflow, with a $\mathrm{ED}_{50}$ value of approx. 0.4 and $0.9 \mathrm{nmol}$, respectively. The antidiuresis of SP was inhibited by a prior injection of [D-Arg ${ }^{1}, \mathrm{D}-\operatorname{Trp}^{7,9}$, Leu ${ }^{11}$ SP (spantide), an SP-receptor antagonist into the SON. After the injection of SP, urine osmotic pressure was increased by threefold, and the urine level of arginine-vasopressin (AVP) was elevated by 70fold. The effects of SP and [D-Pro $\left.{ }^{2}, D_{-}-T_{r}{ }^{7,9}\right] S P$ were completely blocked by pretreatment with an intravenous injection of $d\left(\mathrm{CH}_{2}\right)_{5}$-D-Tyr(Et)VAVP, an AVP $\left(\mathrm{V}_{1} \mathrm{~V}_{2}\right)$-receptor antagonist. A prior injection of atropine, a muscarinic receptor antagonist, inhibited the effect of $\left[\mathrm{D}-\mathrm{Pro}^{2}, \mathrm{D}-\operatorname{Trp}^{7,9}\right] \mathrm{SP}$, but not that of SP. The results suggest that SP, injected into the SON, causes antidiuresis through the release of AVP. A possible mechanism for the antidiureses induced by SP and [D-Pro $\left.{ }^{2}, \mathrm{D}-\mathrm{Trp}^{7,9}\right] \mathrm{SP}$ is discussed.
\end{abstract}

Keywords: Substance P, Antidiuresis, Supraoptic nucleus, Vasopressin, Substance P antagonist

Substance P (SP), a member of the tachykinin family of bioactive peptides, is suggested to be a neurotransmitter or a neuromodulator in the central and peripheral nervous system (1-3). Immunohistochemical studies have shown that SP terminals are found not only in the spinal cord (4) and the substantia nigra (5), but also in the hypothalamus $(6,7)$. Therefore, the involvement of SP in physiological functions in the hypothalamus such as stimulation of arginine-vasopressin (AVP), growth hormone and prolactin release has been suggested $(8-10)$.

The hypothalamic supraoptic nucleus (SON), as well as the paraventricular nucleus (PVN), contains cell bodies of vasopressinergic neurons that synthesize and release AVP. Stimulation of vasopressinergic neurons by neurotransmitters and neuromodulators induces a release of AVP, eventually causing antidiuresis through the renal AVP $\left(V_{2}\right)$ receptors $(11,12)$. By injecting various drugs into the SON or PVN, we have previously shown that cholinergic $(13,14)$, adrenergic $(15,16)$ and enkephalinergic mechanisms $(17,18)$ may control the urine outflow through a stimulation of AVP release.

\footnotetext{
* deceased
}

The vasopressinergic cell bodies in the SON or PVN make synaptic contact with SP-containing nerve terminals (6). It was demonstrated that intraventricular injection of SP induced a prolonged antidiuresis in water-loaded rat (19) and an increase in firing frequency of the SON (20). However, the effect of SP microinjected directly into the vasopressinergic nuclei on the AVP release remains unclear. In this study, we examined the effects of SP and its analog $\left[\mathrm{D}-\mathrm{Pro}^{2}, \mathrm{D}-\operatorname{Trp}^{7,9}\right] \mathrm{SP}$ on the outflow, osmotic pressure and AVP level of urine by injection into the SON in water-loaded and ethanol-anesthetized rats. The influences of pretreatments with AVP-receptor, SP-receptor and muscarinic receptor antagonists on the SP-induced antidiuresis were also examined. The present data showed that SP causes antidiuresis through the release of AVP.

\section{MATERIALS AND METHODS}

\section{Animals and drugs}

Male Wistar rats, weighing $280-330 \mathrm{~g}$, were used. Substance P, [D-Pro ${ }^{2}$, D-Trp $\left.^{7,9}\right] \mathrm{SP}$ and [D-Arg ${ }^{1}, \mathrm{D}-\mathrm{Trp}^{7,9}$, Leu ${ }^{11}$ SSP (spantide) (Peptide Institute, Inc., Osaka), and atropine sulfate (Sigma Chemical Co., St. Louis, MO, 
USA) were purchased. For radioimmunoassay (RIA), AVP-RIA kit (Mitsubishi Petrochemical Co., Ltd., Tokyo) and standard AVP (grade V, Sigma Chemical Co.) were used. Vasopressin antagonist, 1-( $\beta$-mercapto$\beta, \beta$-cyclopentamethylene propionic acid) 2-( $O$-ethyl)-Dtyrosine, 4-valine, arginine vasopressin: $\mathrm{d}\left(\mathrm{CH}_{2}\right)_{5}$-D-Tyr(Et)VAVP, was kindly provided by Prof. K.G. Hofbauer (Cardiovascular Research Department, Pharmaceutical Division, Ciba-Geigy, Ltd., Basel, Switzerland).

\section{Measurement of outflow and osmotic pressure of urine}

Urine outflow was measured by the method of Dicker (21) with some modifications (13). The rats were starved overnight but allowed free access to water. The animals were loaded orally through a catheter with a volume of water equivalent to $5 \%$ of the body weight followed by the same volume of $12 \%$ ethanol. Cannulae were inserted into the trachea, bladder and external jugular vein. The rat was then immobilized in a stereotaxic instrument (Takahashi Co., Tokyo). Drops of urine flowing from the urinary cannula were counted by a photoelectric drop counter (DCT 102, Unique Medical, Inc., Tokyo) and recorded as single pulses. Ethanol (3\% in Locke solution) was infused at a constant rate of $0.10 \mathrm{ml} / \mathrm{min}$ through the cannula in the jugular vein in order to maintain a constant level of anesthesia and a constant rate of urine outflow. Osmotic pressure of the urine was measured by the freezing point depression method (The Fiske Osmometer, Model G-62, Fiske Associates, Inc., Uxbridge, MA, USA).

\section{Injection of drugs}

A stainless steel cannula (outer diameter: $200 \mu \mathrm{m}$ ) was unilaterally inserted stereotaxically into the SON (A, $6.28 ; \mathrm{L}, 1.3 ; \mathrm{H}, 8.8 \mathrm{~mm}$ ) according to the atlas of König and Klippel (22). After the urine outflow had reached a constant rate of $0.06-0.10 \mathrm{ml} / \mathrm{min}, 1 \mu \mathrm{l}$ of the drug solution was injected through a microsyringe connected to the cannula. Then $2 \mu 1$ of an artificial cerebrospinal fluid (CSF: $128 \mathrm{mM} \mathrm{NaCl}, 3.0 \mathrm{mM} \mathrm{KCl}, 1.2 \mathrm{mM} \mathrm{CaCl}_{2}, 0.8$ $\mathrm{mM} \mathrm{MgCl}, 0.65 \mathrm{mM} \mathrm{NaH}_{2} \mathrm{PO}_{4}, 4.8 \mathrm{mM} \mathrm{NaHCO}_{3}, \mathrm{pH}$ 7.4) was injected at a rate of approx. $0.3 \mu 1 / \mathrm{min}$. Effects of drugs on urine outflow were measured at 10 -min intervals and expressed as a percent of the initial control urine outflow. In the experiments to test the effect of pretreatment with spantide, an SP-receptor antagonist (23), the first injection of SP was followed by an injection of the antagonist, and then the second injection of SP was carried out. The injections of the antagonist and SP were carried out after the urine outflow returned to the initial level (approx. 60-80 min). The effects of pretreatment with $\mathrm{d}\left(\mathrm{CH}_{2}\right)_{5}$-D-Tyr(Et)VAVP, an AVP-receptor antagonist, were examined by the same procedure as used for the SP- receptor antagonist except that the AVP-receptor antagonist $(50 \mu \mathrm{g} / \mathrm{kg})$, dissolved in saline, was injected intravenously through the cannula in the external jugular vein at $40 \mathrm{~min}$ before the second injection of SP. The antidiuresis by the second injection of SP or [D-Pro ${ }^{2}, \mathrm{D}$ Trp ${ }^{7,9}$ SP into the SON was approx. equal to that of the first injection of the peptide, showing that the effect was reproducible.

\section{RIA of $A V P$ in urine}

Urine was collected via a bladder catheter and stored at $-20^{\circ} \mathrm{C}$, and measurements were performed within one month. The urine AVP was assayed directly by RIA after diluting the urine $20-100$ times by RIA phosphate buffer to eliminate interference of nonspecific substances. The RIA of AVP was performed as previously described (24). The minimal amount of AVP measurable by the method was approx. $0.063 \mathrm{pg} /$ tube. The inter- and intra-assay coefficients of variation were $4.0 \%$ and $1.3 \%$, respectively.

\section{Measurement of blood pressure, heart rate and respira-} tion rate

Mean blood pressure and heart rate were measured through a cannula inserted into the carotid artery using, respectively, a pressure transducer (MPU-0.5-290-O-III, Nihon Kohden Kogyo Co., Tokyo) and an electrocardiograph (FD-14, Fukuda, Tokyo). Respiration rate was measured via a thermister probe (SR-115S, Nihon Kohden Kogyo Co.) inserted into a tracheal catheter. These three indices were recorded simultaneously on a recticorder (RJG-3004-2, Nihon Kohden Kogyo Co.).

\section{Identification of the sites of cannula insertion}

The position of the tip of the cannula, within the SON, was confirmed by the following methods: 1) functionally, by the appearance of an antidiuresis by the injection of depolarizing doses of $\mathrm{KCl}(800 \mathrm{nmol})$ into the $\mathrm{SON}$ through the cannula and 2) histochemically, by the localization of the site of the tip of the cannula in a group of magnocellular cells in the SON, positively stained by the method of Gomori (25).

\section{Statistical analyses}

Student's $t$-test was used for statistical analyses of the paired test. The differences were considered significant at $\mathrm{P}<0.05$. Unless specified, data are expressed as means \pm S.E., and $\mathbf{n}$ indicates the number of preparations used. The $\mathrm{ED}_{50}$ values and $95 \%$ confidence limit of the $E D_{50}$ values for $S P$ and its analog were calculated from the dose-effect curves, which were drawn using the least squares method. 


\section{RESULTS}

\section{Effects of SP and its analog on urine outflow}

Substance $P$ ( 1 and $5 \mathrm{nmol}$ ) microinjected into the SON decreased the urine outflow (Fig. 1a). An analog of SP, [D-Pro $\left.{ }^{2}, \mathrm{D}-\operatorname{Trp}^{7,9}\right] \mathrm{SP}(1$ and $10 \mathrm{nmol})$ also decreased the urine outflow (Fig. 1b). The urine outflow was usually decreased within $20 \mathrm{~min}$, with a minimum outflow (approx. $20 \%$ of the initial urine outflow) at $20 \mathrm{~min}$ after the injection. The outflow almost returned to the initial control level at 60-80 $\mathrm{min}$. The dose-effect curves for the antidiureses of SP and the SP analog at $20 \mathrm{~min}$ after injection are shown in Fig. 2. The $E D_{50}$ values for $S P$ and [D$\left.\mathrm{Pro}^{2}, \mathrm{D}-\operatorname{Trp}^{7,9}\right] \mathrm{SP}$ were calculated as $0.4(0.13-1.2)$ and

a)

b)

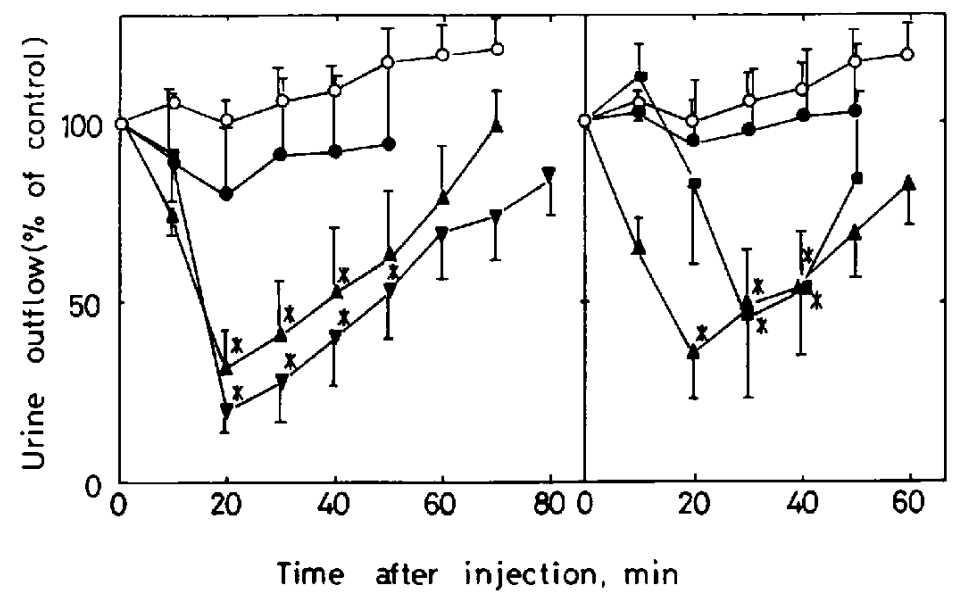

Fig. 1. Effects of increasing doses of SP and [D-Pro $\left.{ }^{2}, D-\operatorname{Trp}^{7,9}\right] \mathrm{SP}$ on the urine outflow, as a function of time, after injection into the SON. In a), $O$ : vehicle (CSF) alone $(n=3), 0: 0,1(n=5), \Delta: 1(n=7), \nabla: 5(n=7)$ nmol of SP. In b), $\bigcirc:$ vehicle (CSF) alone $(n=3), 0: 0.1(n=4), \Delta: 1(n=10), \square: 10(n=5)$ nmol of $\left[D-P r 0^{2}, D-T r p{ }^{7,9}\right] S P$. Ordinate: rate of urine outflow, during the preceding period of $10 \mathrm{~min}$, expressed as a percent of the rate of initial urine outflow (control) [a): $0.074 \pm 0.008 \mathrm{ml} / \mathrm{min}$, $\mathrm{n}=22, \mathrm{~b}$ ): $0.088 \pm 0.022 \mathrm{ml} / \mathrm{min}, \mathrm{n}=22$ ]. Abscissa: Time (min) after injection. Symbols are the mean \pm S.E. of the number of preparations described above. Significance compared with the effect of injection of vehicle at the same time point after injection: ${ }^{*} \mathrm{P}<0.05$.

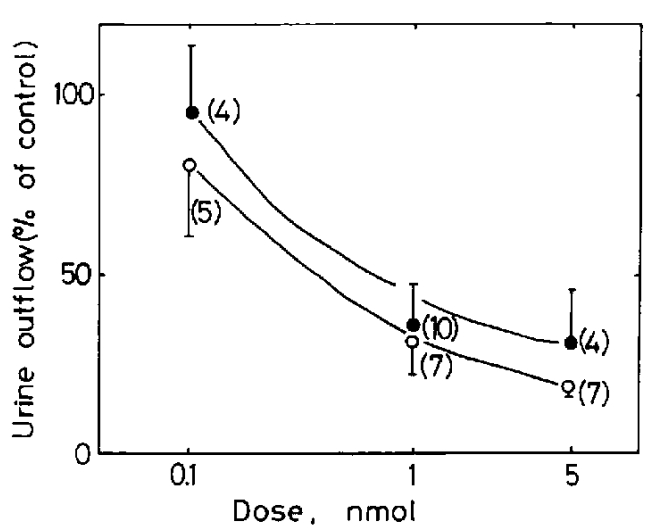

Fig. 2. Dose-effect curves of antidiureses of $S P$ and $\left[D-P r O^{2}, D-\right.$ $\operatorname{Trp}^{7,9}$ ]SP injected into the SON. O: SP, $:$ : [D-Pro $\left.{ }^{2}, \mathrm{D}-\mathrm{Trp}^{7,9}\right] \mathrm{SP}$. Ordinate: rate of urine outflow measured at $20 \mathrm{~min}$ after the injection of SP and the SP analog, expressed as a percent of the initial urine outflow. Abscissa: dose (nmol) of SP and the SP analog. Symbols are the mean $\pm S$.E. of the number of preparations indicated in parentheses.

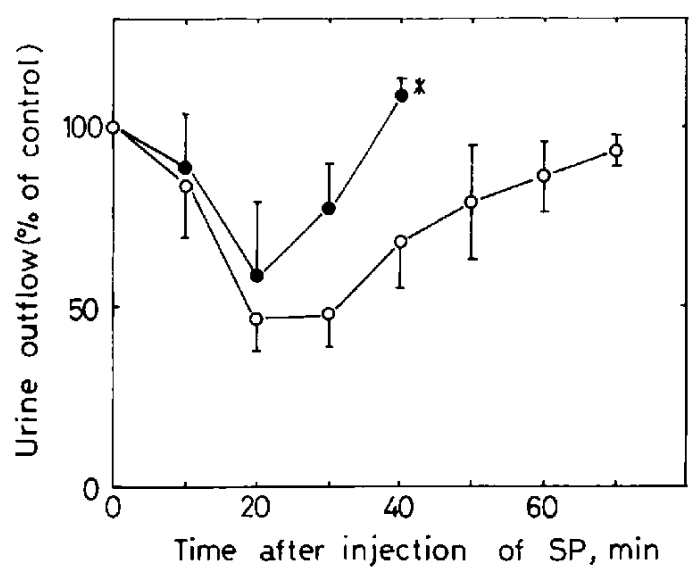

Fig. 3. Effects of prior injection of spantide into the SON on the SP-induced antidiuresis. $O$ : first injection of SP (1 nmol), $O$ : second injection of SP $(1 \mathrm{nmol})$ after injection of spantide $(10 \mathrm{nmol})$. Data are plotted as in Fig. 1. The initial urine outflow: $(\bigcirc$ : $0.087 \pm 0.025 \mathrm{ml} / \mathrm{min}, \mathrm{n}=5$, $: 0.089 \pm 0.013 \mathrm{ml} / \mathrm{min}, \mathrm{n}=5$ ). Symbols are the mean \pm S.E. of 5 preparations. Significance compared with the effects of the first injection of SP at the same time after injection: ${ }^{*} \mathrm{P}<0.05$. 
$0.9(0.45-1.6)$ nmol, respectively.

\section{Effects of spantide on SP-induced antidiuresis}

Spantide (10 nmol), an SP-receptor antagonist, when injected into the SON, significantly decreased the urine outflow by approx. $38 \pm 17 \%(n=7)$. This antagonist caused a weak inhibition of the antidiuresis of SP (1 nmol) because the inhibition was observed only at $40 \mathrm{~min}$ after the injection, as illustrated in Fig. 3. The pretreatment with the antagonist recovered the urine outflow decreased by the injection of SP earlier than injection of SP alone.

\section{Effects of SP on the urine osmotic pressure}

Table 1 shows the effect of SP on the osmotic pressure of urine, as compared to its effects on urine outflow. The osmotic pressure increased to approx. $300 \%$ of the initial control value at $20-30 \mathrm{~min}$ after the injection of SP (1 nmol), when the outflow was decreased to a minimal level (approx. $20 \%$ of the initial control value). When the urine outflow almost returned to the initial level, at 50-100 min after injection, the osmotic pressure also returned to the initial control value. After an injection of AVP (4 $\mathrm{mU})$ which decreased the urine outflow, the osmotic pressure increased to approx. $340 \%$ of the initial control value. Vehicle (CSF) alone, when injected into the nucleus, affected neither the osmotic pressure nor the urine outflow.

\section{Effects of SP on urine level of AVP}

As shown in Table 2, the level of AVP in the urine was elevated to approx. 70 times the initial control level at 20-30 min after the injection of SP (1 nmol). Although the urine outflow almost returned to the initial control value at $40-70 \mathrm{~min}$ after injection of SP, the level of AVP in the urine was significantly higher than the initial control level. After an intravenous injection of AVP (4 $\mathrm{mU})$ which decreased the urine outflow, the urine AVP level was elevated to approx. 100 times the initial level. Vehicle (CSF) alone did not affect the urine AVP level.

Table 1. Effects of SP and AVP on urine osmotic pressure and urine outflow

\begin{tabular}{lclccc}
\hline \multicolumn{1}{c}{ Drug } & $\mathrm{n}$ & & \multicolumn{2}{c}{ Time after injection (min) } \\
& & & 0 & $20-30$ & $50-100$ \\
\hline $\begin{array}{l}\text { CSF injected } \\
\text { into the SON }\end{array}$ & 4 & $\begin{array}{l}\text { urine osmotic pressure (\%) } \\
\text { urine outflow (\%) }\end{array}$ & 100 & $102 \pm 4$ & $106 \pm 12$ \\
& & 100 & $106 \pm 9$ & $119 \pm 15$ \\
$\begin{array}{l}\text { SP 1 nmol injected } \\
\text { into the SON }\end{array}$ & 6 & $\begin{array}{l}\text { urine osmotic pressure (\%) } \\
\text { urine outflow (\%) }\end{array}$ & 100 & $307 \pm 38^{*}$ & $116 \pm 8^{-}$ \\
$\begin{array}{l}\text { AVP 4 mU injected } \\
\text { intravenously }\end{array}$ & 3 & urine osmotic pressure (\%) & 100 & $21 \pm 5^{*}$ & $108 \pm 23^{-}$ \\
& & urine outflow (\%) & 100 & $338 \pm 59^{*}$ & $109 \pm 12^{*}$ \\
\hline
\end{tabular}

Values are the mean \pm S.E., and $n$ indicates the number of preparations used. Values of urine osmotic pressure and outflow were expressed as $\%$ of the control (initial urine osmotic pressure: $214 \pm 15$ mOsm, $\mathrm{n}=13$; initial urine outflow: $0.100 \pm 0.016 \mathrm{ml} / \mathrm{min}, \mathrm{n}=13$ ). ${ }^{*} \mathrm{P}<0.05$, significantly different from the value of $\mathrm{CSF} .{ }^{+} \mathrm{P}<0.05$, significant difference between the value at $20-30 \mathrm{~min}$ and that at 50-100 min.

Table 2. Effects of SP and AVP on AVP level in unextracted urine

\begin{tabular}{|c|c|c|c|c|c|}
\hline \multirow{2}{*}{ Drug } & \multirow{2}{*}{$\mathrm{n}$} & & \multicolumn{3}{|c|}{ Time after injection (min) } \\
\hline & & & 0 & $20-30$ & $40-70$ \\
\hline \multirow{2}{*}{$\begin{array}{l}\text { CSF injected } \\
\text { into the SON }\end{array}$} & \multirow{2}{*}{3} & urine AVP $(\mathrm{pg} / \mathrm{ml})$ & $6.7 \pm 3.6$ & $3.1 \pm 0.7$ & - \\
\hline & & urine outflow $(\%)$ & 100 & $105 \pm 11$ & - \\
\hline \multirow{2}{*}{$\begin{array}{l}\text { SP } 1 \text { nmol injected } \\
\text { into the SON }\end{array}$} & \multirow{2}{*}{5} & urine AVP $(\mathrm{pg} / \mathrm{ml})$ & $2.3 \pm 0.5$ & $159.3 \pm 63.1^{*}$ & $8.2 \pm 2.2^{*}$ \\
\hline & & urine outflow $(\%)$ & 100 & $21 \pm 4.5^{+}$ & $131.4 \pm 16.5$ \\
\hline \multirow{2}{*}{$\begin{array}{l}\text { AVP } 4 \mathrm{mU} \text { injected } \\
\text { intravenously }\end{array}$} & \multirow{2}{*}{4} & urine AVP $(\mathrm{pg} / \mathrm{ml})$ & $5.9 \pm 2.6$ & $566 \pm 223^{*}$ & $8.9 \pm 1.9$ \\
\hline & & urine outflow $(\%)$ & 100 & $8.3 \pm 1.9^{+}$ & $130.8 \pm 23.3$ \\
\hline
\end{tabular}

Values are the mean \pm S.E., and $\mathrm{n}$ indicates the number of preparations used. Values of urine outflow were expressed as $\%$ of the control (initial urine outflow: CSF, $0.075 \pm 0.015(n=3) ;$ SP, $0.094 \pm 0.019(n=5) ; A V P, 0.106 \pm 0.032$ $\mathrm{ml} / \mathrm{min}, \mathrm{n}=4)$. ${ }^{*} \mathrm{P}<0.05$, significantly different from the corresponding value at $0 \mathrm{~min} .{ }^{+} \mathrm{P}<0.05$, significantly different from the value of CSF. 
Inhibition by an $A V P$ receptor antagonist of the antidiureses induced by $S P$ and its analog

As shown in Fig. 4 , the AVP $\left(V_{1} V_{2}\right)$ receptor antagonist, d( $\left(\mathrm{CH}_{2}\right)_{5}$-D-Tyr(Et)VAVP ( $\left.50 \mu \mathrm{g} / \mathrm{kg}\right)$, injected intravenously at $40 \mathrm{~min}$ before the injection of SP and [DPro $^{2}, \mathrm{D}-\operatorname{Trp}^{7,9}$ ]SP ( $\left.1 \mathrm{nmol}\right)$, abolished the antidiureses of SP and the analog. The AVP-receptor antagonist alone had no effects on the urine outflow.

\section{Effects of atropine on the antidiureses of $S P$ and its analog}

Atropine $(300 \mathrm{nmol})$, when injected into the SON at 20 min before the injection of SP, did not inhibit the anti- diuresis of SP (1 nmol, Fig. 5a). However, atropine significantly inhibited the antidiuresis of [D-Pro $\left.{ }^{2}, \mathrm{D}-\operatorname{Trp}^{7,9}\right]$ SP (1 nmol). Atropine ( $300 \mathrm{nmol})$ alone had no effects on the urine outflow.

\section{Cardiovascular and respiratory effects of $S P$}

Some visceral functions, which may be caused by SP, and which may influence the urine outflow, were monitored during the experiments. However, no significant changes in blood pressure, heart rate and respiration rate were observed by the injection of SP $(1 \mathrm{nmol}, \mathrm{n}=4)$ (data not shown).

a)

b)

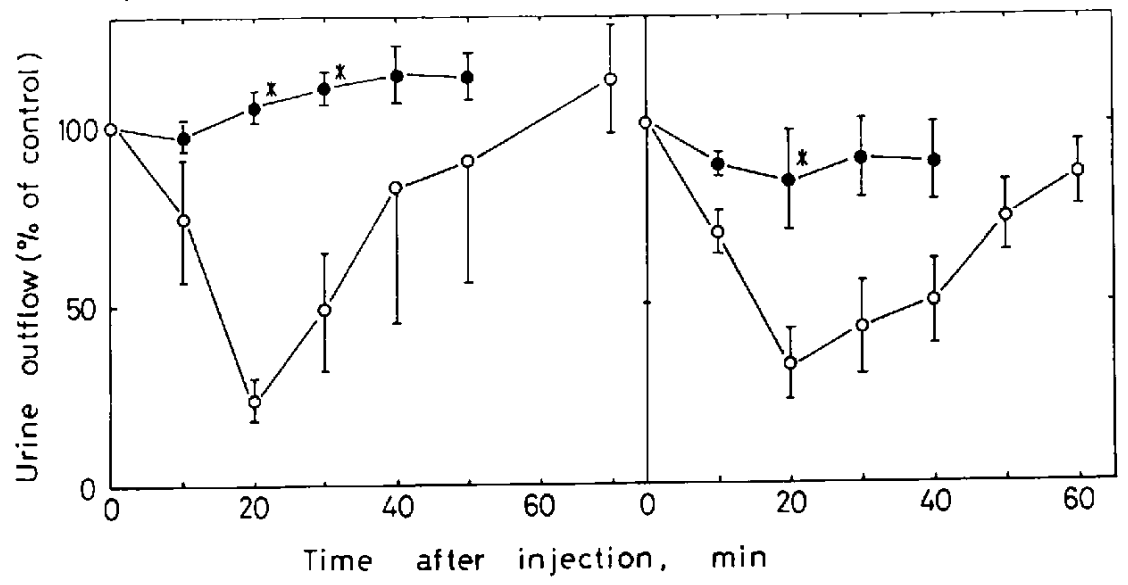

Fig. 4. Effects of prior intravenous injection of $\mathrm{d}\left(\mathrm{CH}_{2}\right)_{5}$-D-Tyr(Et)VAVP on the SP- and [D-Pro ${ }^{2}$, D-Trp $\left.{ }^{7,9}\right] \mathrm{SP}-\mathrm{induced}$ antidiureses. $O$ : first injection of $1 \mathrm{nmol} \mathrm{SP}[\mathrm{a})]$ or $\left.1 \mathrm{nmol}\left[\mathrm{D}-\mathrm{Pro}^{2}, \mathrm{D}-\mathrm{Trp}^{7,9}\right] \mathrm{SP}[\mathrm{b})\right]$. $\mathrm{O}$ : second injection of the peptide (1 nmol) after a 40-min pretreatment with d $\left(\mathrm{CH}_{2}\right)_{5}$-D-Tyr(Et)VAVP $(50 \mu \mathrm{g} / \mathrm{kg}$, i.v. $)$. Data are plotted as in Fig. 1 . The initial urine outflow: [a): $0.070 \pm 0.011 \mathrm{ml} / \mathrm{min}, \mathrm{n}=3 ; \mathrm{b}): 0.057 \pm 0.011 \mathrm{ml} / \mathrm{min}, \mathrm{n}=3$ ]. Significance compared with the effects of the first injection of SP or the SP analog at the same time after injection: ${ }^{*} \mathrm{P}<0.05$.

a)

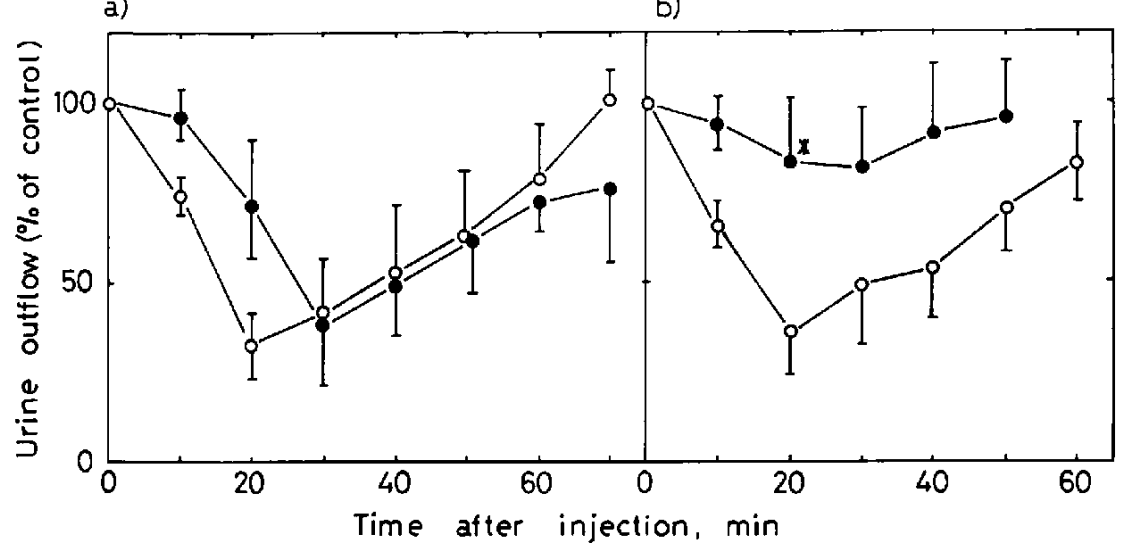

Fig. 5. Effects of a prior injection of atropine into the SON on the SP- and [D-Pro $\left.{ }^{2}, D_{-}-T_{r p}{ }^{7,9}\right] S P$-induced antidiureses. $O$ : first injection of $1 \mathrm{nmol}$ SP [a)] or $\left.1 \mathrm{nmol}\left[\mathrm{D}-\mathrm{PIO}^{2}, \mathrm{D}-\mathrm{T}_{\mathrm{rp}}{ }^{7,9}\right] \mathrm{SP}[\mathrm{b})\right]$. : second injection of the drug after pretreatment with atropine $(300 \mathrm{nmol})$. Data are plotted as in Fig. 1. The initial urine outflow: [a): $0.089 \pm 0.012 \mathrm{ml} / \mathrm{min}, \mathrm{n}=6, \mathrm{~b}): 0.077 \pm 0.035 \mathrm{ml} / \mathrm{min}$, $\mathbf{n}=5$ ]. Significance compared with the effects of the first injection of SP or the SP analog at the same time after injection: ${ }^{*} \mathrm{P}<0.05$. 


\section{DISCUSSION}

The present study shows that SP and its analog [D-Pro ${ }^{2}$, $\left.\mathrm{D}-\operatorname{Trp}^{7,9}\right] \mathrm{SP}$, when injected into the SON, induce marked decreases in urine outflow. The time-course of the effects of SP and the analog, which began within $20 \mathrm{~min}$, peaking at $20 \mathrm{~min}$, and disappearing at $60-80 \mathrm{~min}$ after injection, was comparable to those of drugs such as cholinergic, adrenergic and enkephalinergic agonists which have been previously reported $(13-18)$. The relatively slow time-course of these effects suggests that the effects are mediated through hormonal pathways such as a release of AVP rather than neuronal pathways. When the $\mathrm{ED}_{50}$ values for these agonists inducing antidiureses were compared, SP $(0.4 \mathrm{nmol})$ and the analog $(0.9 \mathrm{nmol})$ were much more potent than ACh $(80 \mathrm{nmol}$, ref. 13) and noradrenaline (NA) (20 nmol, ref. 15), but were similar to D-alanine-5-methionine-enkephalinamide $(1.3 \mathrm{nmol}$, ref. 17).

Injection of a 1- $\mu 1$ volume of the effective dose of antidiuretic agonists, such as oxotremorine or NA, at a distance of $1 \mathrm{~mm}$ outside the SON, did not induce any significant effects on the urine outflow. The diffusion range after microinjection of methylene blue $(1 \mu \mathrm{l})$ demonstrated that the distance of simple diffusion of microinjected SP was less than $1 \mathrm{~mm}$. These results suggest that SP acts directly on the SON.

As the effect of SP on the urine outflow was inhibited by a pretreatment with the SP-receptor antagonist spantide (23), SP regulates the urine outflow through an SP receptor. Although Buck and Shatzer (26) suggested that spantide is an antagonist with preference for the neurokinin-1 receptor, the receptor selectivity of the antagonist is still in question (27-29). On the other hand, the finding that the selective neurokinin-3 receptor agonists stimulate the AVP release $(30,31)$ indicates the possible involvement of the central neurokinin-3 receptors in the AVP release induced by tachykinins. Therefore, the weak inhibition by spantide on SP-induced antidiuresis in this study may be due to the receptor selectivity of this antagonist. As an alternative reason, the antagonistic effect of spantide may reduce at $60-80 \mathrm{~min}$ after injection of the antagonist, since the duration of spantide $\Pi$ is relatively short (approx. $60 \mathrm{~min}$, ref. 32). Further studies using neurokinin receptor subtype-specific agonists or antagonists are required to clarify the receptor subtype involved in the AVP release.

The SP-induced decrease in the urine outflow was associated with increases in the osmotic pressure (threefold) and AVP level (70-fold) of urine. This effect on osmotic pressure was similar to those induced by $\mathrm{ACh}, \mathrm{NA}$ and opioids $(13-18)$. The increase in urine AVP level probably reflects an increase in plasma AVP level $(24,33)$. The urine AVP level can be measured by radioimmunoassay without prior extraction. The interference by a nonspecific substance which was observed in the plasma AVP extract can be eliminated by dilution of the urine. When the urine was diluted to $20-100$ volumes with an assay buffer, the relationship between urine AVP level and dilution ratio was nearly linear. At 40-70 min after injection of SP when the urine outflow and osmotic pressure returned to the initial level, the urine AVP level was still elevated. The time course of the effect of SP on urine outflow and osmotic pressure may be different from that on AVP level. In addition, the decrease in urine outflow by $\mathrm{SP}$ was almost completely blocked by a pretreatment with an intravenous injection of the AVP $\left(\mathrm{V}_{1} \mathrm{~V}_{2}\right)$-receptor antagonist, which has a higher sensitivity for the renal $V_{2-}$ receptors (34). These results suggest that the injection of SP into the SON stimulates the AVP release. In the SON, SP may enhance the AVP release from neurohypophysis and reabsorption of water from the kidney by stimulating the renal $\mathrm{V}_{2}-\mathrm{AVP}$ receptors. This study indicates the possibility that in addition to the cholinergic, adrenergic and opioid peptidergic neurons, SP-containing neurons also play important roles in the regulation of AVP release.

Synthetic analogs of SP with antagonistic properties have been developed. [D-Pro $\left.{ }^{2}, \mathrm{D}-\operatorname{Trp}^{7,9}\right] \mathrm{SP}$ used in this study has also a specific antagonistic activity on smooth muscle preparations (35) and neurons in the locus coeruleus (36). In this study, the two SP analogs, [D-Pro', D-Trp ${ }^{3,9}$ SP and spantide, injected into the SON, caused decreases in urine outflow, like SP. The former analog has a similar potency to SP, while the latter analog was less potent than SP. Since the effect by the former analog was abolished by a pretreatment with an intravenous injection of the AVP $\left(\mathrm{V}_{1} \mathrm{~V}_{2}\right)$-receptor antagonist, this analog may stimulate the AVP release. The antagonistic analog may act as an agonist in the SON as already demonstrated in the locus coeruleus (37).

In this study, however, [D-Pro $\left.{ }^{2}, \mathrm{D}^{-} \operatorname{Trp}^{7,9}\right] \mathrm{SP}(1 \mathrm{nmol})$ did not inhibit the SP (1 nmol)-induced antidiuresis, suggesting that the antagonistic activity of the SP analog is less potent in the SON. Therefore, much higher doses of the SP analog may be needed to exert the antagonistic effect against SP. Since high doses of [D-Pro $\left.{ }^{2}, \mathrm{D}-\operatorname{Trp}^{7,9}\right]-$ SP induce a neurotoxic effect (38), further studies are necessary to elucidate the antagonistic effect of the SP ana$\log$.

It is unknown why atropine inhibits the [D-Pro ${ }^{2}$, D$\left.\operatorname{Tr} \mathrm{p}^{7,9}\right] \mathrm{SP}$-induced antidiuresis, but not the SP-induced effect. The inability of atropine to inhibit the SP-induced effect was unexpected, since this finding differs from the demonstration that SP evoked the ACh release from spinal neurons (39). One possible explanation of this finding is that the effect of [D-Pro $\left.{ }^{2}, \mathrm{D}-\mathrm{Trp}^{7,9}\right] \mathrm{SP}$ may be mediated 
by a cholinergic mechanism in the SON. However, further studies are needed to investigate the difference in mechanisms between them.

One nanomole of SP injected into the SON did not affect cardiovascular functions such as blood pressure, heart rate and respiratory rate, although it induced marked antidiuresis. This finding indicates the effect of SP on urine outflow is not due to the change in hemodynamics. Some investigations have shown that SP affected cardiovascular function even by intracerebroventricular injection or microinjection into the nucleus tractus solitarii $(10,31,40-42)$. The difference in the results between these studies and the present study may be due to a difference in the site of injection.

In conclusion, the results suggest that $\mathrm{SP}$ and $\left[\mathrm{D}-\mathrm{Pro}^{2}\right.$, D- $\operatorname{Trp}^{7,9} \mathrm{SSP}$, injected into the SON, stimulate the AVP release through the activation of SP receptors, inducing the antidiureses. The effect of the SP analog may be partly mediated through a different mechanism from that of SP.

\section{Acknowledgments}

The study was supported in part by a Grant-in-Aid for Scientific Research from the Ministry of Education, Science and Culture of Japan. We would like to thank Professor K.G. Hofbauer, Cardiovascular Research Department, Pharmaceutical Division, CibaGeigy Ltd., Basel, Switzerland, for providing the AVP-receptor antagonist.

\section{REFERENCES}

1 Otsuka, M., Konishi, S. and Takahashi, T.: Hypothalamic substance $P$ as candidate for transmitter of primary afferent neurons. Fed. Proc. 34, 1922-1928 (1975)

2 Haeulser, G. and Osterwalder, R.: Evidence suggesting a transmitter or neuromodulatory role for substance $P$ at the first synapse of the baroreceptor reflex. Arch. Pharmacol. 314, $111-121$ (1980)

3 Pernow, B.: Substance P. Pharmacol. Rev, 5, 85-141 (1983)

4 Barber, R.P., Vaughn, J.E., Slemmon, J.R., Salyaterra, P.M., Roberts, E. and Leeman, S.E.: The origin, distribution and synaptic relationships of substance $\mathbf{P}$ axons in rat spinal cord. $\mathbf{J}$. Comp. Neurol. 184, 331-352 (1979)

5 Somogyi, P., Priestley, J.V., Cuello, A.C., Smith, A.D. and Bolan, J.P.: Synaptic connections of substance P-immunoreactive nerve terminals, in the substantia nigra of the rat. A correlated light- and electron-microscopic study. Cell Tissue Res. 223, 469-486 (1982)

6 Heike, Y., Hisano, S., Tsuruo, Y., Katoh, S. and Daikoku, S.: Immunocytochemical evidence for synaptic regulation of paraventricular vasopressin-containing neurons by substance $P$. Brain Res. 369, $341-346$ (1986)

7 Sladek, C.D. and Armstrong, W.E.: Neural pathways subserving osmotic control of vasopressin release. In Vasopressin, Edited by Schrier, R.W., pp. 435-441, Raven, New York (1985)

8 Kato, Y., Chihara, K., Ohgo, S., Iwasaki, Y., Abe, H. and Imura, H.: Growth hormone and prolactin release by substance $P$ in rats. Life Sci. 19, 441-446 (1976)
9 Vijayan, E. and McCann, S.M.: Effects of substance P and neurotensin on growth hormone and thyrotropin release in vivo and vitro. Life Sci. 26, 321-327 (1980)

10 Unger, T., Rasher, W., Schuster, C., Pavlovitch, R., Schömig, A., Dietz, R. and Gantan, D.: Central blood pressure effects of substance $P$ and angiotensin $I$ : Role of the sympathetic nervous system and vasopressin. Eur. J. Pharmacol. 71, 33-42 (1981)

11 Zimmerman, E.A.: Oxytocin, vasopressin and neurophysins. In Brain Peptides, Edited by Krieger, D.T., Brownstein, M.J. and Martin, J.B., pp. 597-611, Wiley, New York (1983)

12 Manning, M. and Sawer, W.H.: Development of selective agonists and antagonists of vasopressin and oxytocin. In Vasopressin, Edited by Schrier, R.W., pp. 131-144, Raven, New York (1985)

13 Mori, M., Tsushima, H. and Matsuda, T.: Antidiuretic effects of oxotremorine microinjected into the hypothalamic supraoptic and paraventricular nuclei in a water-loaded and ethanolanesthetized rat. Japan. J. Pharmacol. 35, 27-36 (1984)

14 Mori, M., Tsushima, H. and Matsuda, T.: Effect of vasopressin antagonist on antidiuresis by oxotremorine microinjected into the hypothalamic supraoptic and paraventricular nuclei in a water-loaded and ethanol-anesthetized rat. Japan. J. Pharmacol. 49, 357-364 (1989)

15 Tsushima, H., Mori, M. and Matsuda, T.: Antidiuretic effects of alpha- and beta-adrenoceptor agonists microinjected into the hypothalamic supraoptic nucleus in water-loaded and ethanolanesthetized rat. Japan. J. Pharmacol. 39, 365-374 (1985)

16 Tsushima, H., Mori, M. and Matsuda, T.: Antidiuretic effects of alpha- and beta-adrenoceptor agonists microinjected into the hypothalamic paraventricular nucleus in water-loaded and ethanol-anesthetized rat. Japan. J. Pharmacol. 40, 319-328 (1986)

17 Tsushima, H., Mori, M. and Matsuda, T.: Antidiuretic effects of methionine-enkephalin and 2-D-alanine-5-methionineenkephalinamide microinjected into the hypothalamic supraoptic and paraventricular nuclei in water-loaded and ethanolanesthetized rat. Japan. J. Pharmacol. 42, 507-515 (1986)

18 Tsushima, H., Mori, M. and Matsuda, T.: Effects of fentanyl, injected into the hypothalamic supraoptic and paraventricular nuclei, in a water-loaded and ethanol-anesthetized rat. Neuropharmacology 29, 757-763 (1990)

19 Halder, J., Hoffman, D.L., Nilaver, G. and Zimmerman, E.A.: Oxytocin and vasopressin release by substance $P$ injected into the cerebral ventricle of rats. Soc. Neurosci. Abstr. 5, 447 (1979)

20 Clarke, G., Kirby, P.J.C. and Thomson, A.M.: Effects on vasopressinergic and oxytocinergic neurons of intraventricular substance P. J. Physiol. (Lond.) 307, 59p-60p (1980)

21 Dicker, S.E.: A method for the assay of very small amounts of antidiuretic activity with a note on the antidiuretic titre of rat's blood. J. Physiol. (Lond.) 122, 149-157 (1953)

22 König, J.F.R. and Klippel, R.A.: The Rat Brain, a Stereotaxic Atlas of the Forebrain and Lower Parts of the Brain Stem. The Williams and Wilkins, Baltimore (1963)

23 Folkers, K., Håkanson, R., Hörig, J., Jie-Cheng, X. and Leander, S.: Biological evaluation of substance $P$ antagonists. Br. J. Pharmacol. 83, 449-456 (1984)

24 Kondo, K., Otake, K., Iwasaki, Y., Oiso, Y. and Takatsuki, K.: Radioimmunoassay of vasopressin in unextracted random urine; Clinical application for screening of central diabetes inspi- 
dus. Folia Endocrinol, 65, 537-548 (1989) (Abs. in English)

25 Bargmann, W.: Über die neurosekretoriche Verknüpfung von Hypothalamus und Neurohypophyse. Z. Zellforsch. 34, 610-634 (1949) (in German)

26 Buck, S.H. and Shatzer, S.A.: Agonist and antagonist binding to tachykinin peptide NK-2 receptors. Life Sci. 42, 2701-2708 (1988)

27 Yachnis, A.T., Crawley, J.N., Jensen, R.T., McGrane, M.M. and Moody, T.W.: The antagonism of bombesin in the CNS by substance $P$ analogues. Life Sci. 35, $1963-1969$ (1984)

28 Wiesenfeld-Hallin, Z. and Duranti, R.: D-Arg', D-Trp ${ }^{7,9}$, Leu ${ }^{11}$ substance $P$ (spantide) does not antagonize substance $P$-induced hyperexcitability of the nociceptive flexion withdrawal reflex in the rat. Acta Physiol. Scand. 129, 55-59 (1987)

29 Yanagisawa, M. and Otsuka, M.: Pharmacological profile of a tachykinin antagonist, spantide, as examined on rat spinal motoneurones. Br. J. Pharmacol. 100, 711-716 (1990)

30 Polidori, C., Saija, A., Perfumi, M., Costa, G., De Caro, G. and Massi, M.: Vasopressin release induced by intracranial injection of tachykinins is due to activation of central neurokinin3 receptors. Neurosci. Lett. 103, 320-325 (1989)

31 Takano, Y., Nagashima, A., Hagio, T., Tateishi, K. and Kamiya, H.: Role of central tachykinin peptides in cardiovascular regulation in rats. Brain Res. 528, 231-237 (1990)

32 Wiesenfeld-Hallin, Z., Jie-Cheng, X., Kristensson, K., Hảkanson, R., Feng, D.-M. and Folkers, K.: Antinociceptive and substance $P$ antagonistic effects of intrathecally injected spantide II in rat: no signs of motor impairment or neurotoxicity. Regul. Pept. 29, 1- 11 (1990)

33 Bisset, G.W., Fairhall, K.M. and Tsuji, K.: The effect of neosurugatoxin on the release of neurohypophyseal hormone by nicotine, hypotension and an osmotic stimulus in the rat. Br. J. Pharmacol. 106, 685-692 (1992)

34 Hofbauer, K.G., Mah, S.C. and Opperman, J.R.: Chronic blockade of vasopressin receptors in rats. J. Cardiovasc. Pharmacol, 8, Supp. 7, S56-S60 (1986)

35 Leander, S., Håkanson, R., Rosell, S., Folkers, K., Sundler, F. and Tornqvist, K.: A specific substance $P$ antagonist blocks smooth muscle contractions induced by non-cholinergic, nonadrenergic nerve stimulation. Nature 294, 467-469 (1981)

36 Engberg, G., Svensson, T.H., Rosell, S. and Folkers, K.: A synthetic peptide as an antagonist of substance $P$. Nature 293, 222-223 (1981)

37 Cheeseman, H.J., Pinnock, R.D. and Henderson, G.: Substance $P$ excitation of rat locus coeruleus neurons. Eur. J. Pharmacol. 94, 93-99 (1983)

38 Hökfelt, T., Vincent, S., Hellsten, L., Rosell, S., Folkers, K., Markey, K., Goldstein, M. and Cuello, C.: Immunohistochemical evidence for a "neurotoxic" action of [D-Pro $\left.{ }^{2}, \mathrm{D}-\mathrm{Trp}^{7,9}\right]$-substance $P$, an analogue with substance $P$ antagonistic activity. Acta Physiol. Scand. 113, 571-573 (1981)

39 Otsuka, M., Sakuma, M., Kobayashi, N., Onishi, Y., Yanagisawa, M., Suzuki, H. and Yoshida, K.: Tachykininevoked release of neurotransmitters from isolated spinal cord of the newborn rat. Ann. N.Y. Acad. Sci. 632, 212-219 (1991)

40 Trimarchi, G.R., Glisson, W.G., Thomson, W.M., Van Lingen, J. and Buccafusco, J.J.: Cholinergic neurons and the cardiovascular response produced by central injection of substance $P$ in the normotensive rat. Life Sci. 39, 1579-1588 (1986)

41 Kubo, T. and Kihara, M.: Blood pressure modulation by substance $P$ in the rat nucleus tractus solitarius. Brain Res. 413, 379-383 (1987)

42 Itoi, K., Tschöpe, C., Jost, N., Culman, J., Lebrun, C., Stauss, $B$. and Unger, T.: Identification of the central tachykinin receptor subclass involved in substance $P$-induced cardiovascular and behavioral responses in concious rats. Eur. J. Pharmacol. 219 , $435-444$ (1992) 